\title{
STATUS IMUNISASI DAN KETEPATAN PEMBERIAN IMUNISASI CAMPAK PADA ANAK BALITA DI DAERAH YANG PERNAH MENGALAMI KLB CAMPAK NUSA PENIDA
}

\author{
Anak Agung Gede Rudhi Arsana*, Made Pasek Kardiwinata, I Made Sutarga \\ Program Studi Kesehatan Masyarakat Fakultas Kedokteran Universitas Udayana \\ *Email: gungrudhi@yahoo.co.id
}

\begin{abstract}
ABSTRAK
Campak merupakan salah satu dari penyakit menular yang dapat dicegah dengan imunisasi. Pada tahun 2016, diketemukan KLB campak di Pulau Nusa Penida, Kabupaten Klungkung. Secara geografis wilayah pulau Nusa Penida sendiri merupakan wilayah dengan daratan yang terpisah dengan pulau Bali, sehingga jika terjadi suatu kasus maka akan lebih mudah menyebar karena interaksi penduduk hanya sekitaran wilayah pulau tersebut. Padahal cakupan imunisasi dasar campak diwilayah tersebut pada tahun 2015 dan 2016 sudah melebihi target cakupan Nasional, yaitu 90\%. Imunisasi campak seharusnya dapat memberikan kekebalan seumur terhadap serangan penyakit campak sehingga tidak menimbulkan KLB pada suatu wilayah. Tujuan penelitian ini untuk melihat gambaran status imunisasi, ketepatan pemberian imunisasi campak dan kejadian campak pada anak balita didaerah yang pernah mengalami KLB. Desain penelitian ini menggunakan rancangan deskriptif Cross Sectional. Sampel dalam penelitian ini adalah Anak Balita, dan yang menjadi responden adalah Ibu, dengan jumlah 70 sampel. Teknik pengambilan sampel pada penelitian ini yaitu Systematic Random Sampling. Hasil penelitian pada anak balita di daerah yang pernah mengalami KLB campak Nusa Penida, Kabupaten Klungkung menunjukkan bahwa $17,14 \%$ anak balita di daerah tersebut pernah mengalami campak. Berdasarkan status imunisasi, sebagian besar anak balita telah mendapatkan imunisasi dasar campak 74,29\%, namun masih terdapat anak yang mengalami kejadian campak klinis dengan proporsi 3,85\%. Sedangkan untuk ketepatan pemberian imunisasi, sebagian besar anak balita telah diberikan imunisasi dasar campak dengan tepat waktu yaitu usia 9-11 bulan 68,57\%, namun masih terdapat anak balita yang mengalami kejadian campak klinis dengan proporsi 2,08\%. Kejadian campak klinis pada anak balita lumayan tinggi, sangat perlu dilakukan konfirmasi uji laboratorium untuk memastikan kasus tersebut sehingga tepat dalam pengobatannya. Perlu adanya sosialisasi kepada masyarakat akan informasi mengenai pentingnya pemberian imunisasi yang harus diberikan tepat pada waktunya untuk mencegah terjadinya campak.
\end{abstract}

Kata kunci: Status Imunisasi, Ketepatan Pemberian Imunisasi, Campak

\begin{abstract}
One of the infectious diseases that can be prevented by immunization. In 2016, a measles outbreak was discovered on Nusa Penida Island, Klungkung Regency. Geographically, the island of Nusa Penida is an area with land separated from the island of Bali, so that if a case occurs it will be easier to spread because it deals with residents only around the island. Meanwhile, basic immunization seen in the region in 2015 and 2016 has exceeded the National achievement target of $90 \%$. Immunization seems to provide immunity against disease that seems to affect outbreaks in a region. The purpose of this study was to see an overview of immunization status, accuracy of immunization and measles events in children under five years old who have experienced outbreaks. The design of this study used a cross sectional descriptive design. The sample in this study were toddlers, and the respondents were mothers, with a total of 70 samples. The sampling technique in this study is Systematic Random Sampling. The results of research on toddlers in areas that have used outbreaks of measles Nusa Penida, Klungkung Regency show that $17.14 \%$ of children under five in this area have experienced measles. Based on immunization status, most children under five have received basic measles immunization $74.29 \%$, but still are children who have experienced clinical measles with a contribution of $3.85 \%$. As for the accuracy of immunization, most children under five have been given basic immunization that looks right at the age of 9-11 months $68.57 \%$, but still contains children under five who have clinical measles events with a proportion of $2.08 \%$. Clinical incidence in children under five is high, it is necessary to conduct laboratory tests to ensure the case is right for treatment. There is a need for information dissemination to the public about the importance of immunization that must be given exactly when it has to be approved for release.
\end{abstract}

Keywords: Immunization Status, Accuracy in Providing Immunizations, Measles 


\section{PENDAHULUAN}

Campak suatu infeksi virus yang sangat menular, ditandai dengan demam, batuk, konjungtivitis dan ruam kulit. Disebabkan oleh virus measles, termasuk genus Morbilivirus dan familia Paramyxoviridae (WHO). Campak merupakan salah satu dari penyakit yang dapat dicegah dengan imunisasi.

Pemberian imunisasi dasar campak diberikan pertama kali pada umur bayi 9 bulan, karena pada umur tersebut antibodi dari Ibu sudah mulai menurun. Imunisasi campak tersebut penting diberikan untuk menimbulkan kekebalan aktif pada individu. Vaksin campak memiliki efikasi sekitar 85\%, sehingga masih terdapat anak-anak yang belum memiliki kekebalan dan menjadi kelompok rentan terhadap penyakit campak (Kemenkes, 2017).

Perkembangan imunisasi campak memiliki peran yang besar dalam menurunkan angka kematian akibat campak. Secara global selama tahun 20002014, imunisasi campak mencegah kematian 17,1 juta dan terjadi penurunan kematian akibat campak sebesar 79\% dari angka 546.800 tahun 2000, menjadi 114.900 pada tahun 2014 (WHO, 2015).

Pada tahun 2011 Indonesia merupakan negara ASEAN yang memiliki kasus campak klinis terbanyak dengan jumlah 16.529 kasus. Hasil perbaikan pada program imunisasi selama lima tahun terakhir, menunjukkan terjadi penurunan kasus campak hinga setengahnya pada tahun 2015 yaitu 8.185 kasus campak klinis, dengan Incidence Rate (IR) campak pada tahun 2015 sebesar 3,20 per 100.000 penduduk. (Profil Kesehatan RI).
Provinsi Bali sendiri pada tahun 2013 ditemukan 8 kasus campak klinis, meningkat drastis pada tahun 2014, dilaporkan 971 kasus campak klinis dengan IR 9,04 per 100.000 penduduk. Sedangkan pada tahun 2016, diketemukan kasus campak klinis sebanyak 157 kasus.

Selain kasus campak klinis yang diketemukan, masih terjadi KLB campak setiap tahunnya. KLB Campak tertinggi terjadi pada tahun 2014, terjadi 11 KLB dengan Attack Rate sebesar 1,18\%. Sedangkan pada tahun 2016, masih terjadi 3 KLB, dengan kasus campak terbanyak ditemukan di Kabupaten Klungkung. (Seksi Pencegahan Penyakit, Diskes Provinsi Bali)

Menurut Ikatan Dokter Anak Indonesia, cakupan imunisasi harus selalu diperhatikan karena ini sangat penting untuk dapat memantau bagaimana kejadian penyakit campak pada daerah tertentu. Cakupan imunisasi dasar campak di Provinsi Bali selama tiga tahun berturut-turut yaitu 97,6\% (2014), 99,41\% (2015) dan 98,11\% (2016). Sedangkan di Kabupaten Klungkung yaitu sebesar 98,15\% (2014), 100,4\% (2015) dan 101,29\% (2016).

Namun pada Oktober 2016, masih terjadi KLB campak diwilayah kerja Puskesmas Nusa Penida I dengan penderita 27 kasus, terdapat seorang penderita anak balita. Padahal cakupan imunisasi campak diwilayah tersebut pada tahun 2016 sebesar 91,1\%. Berdasarkan laporan investigasi KLB Campak yang terjadi di Nusa Penida, menyatakan bahwa hanya 23 penderita telah mendapatkan imunisasi campak, lainnya belum mendapatkan imunisasi 
campak (Dinkes Klungkung, 2016). Oleh sebab itu maka perlu dilakukan penelitian status imunisasi dengan kejadian campak.

Tujuan penelitian ini untuk mengetahui gambaran status imunisasi, ketepatan pemberian imunisasi campak, dan kejadian campak pada Anak Balita di daerah yang pernah mengalami KLB Campak Nusa Penida.

\section{METODE PENELITIAN}

Desain penelitian ini menggunakan rancangan deskriptif Cross Sectional, yang dilaksanakan di daerah yang pernah mengalami KLB campak pada tahun 2016, yaitu Desa Suana, Desa Kutampi Kaler dan Desa Batununggul Kecamatan Nusa Penida. Populasi dalam penelitian ini adalah anak balita yang tinggal dan menetap di daerah tersebut.

Perhitungan besar sampel size adalah 70 sampel anak balita dengan responden Ibu dari anak balita. Teknik pengambilan sampel pada penelitian ini adalah Systematic Random Sampling. Data yang terkumpul kemudian di analisis dengan menggunakan program stata 12. Analisis yang dilakukan yakni analisis univariate dan bivariate.

\section{HASIL}

\section{Karakteristik Sampel dan Responden}

Karakteristik sampel dan responden menurut jenis kelamin anak balita, tingkat pendidikan ibu, penghasilan keluarga, dan pekerjaan ibu yang disajikan berikut ini.

Tabel 1 Karakteristik Sampel dan Responden Penelitian

\begin{tabular}{lll}
\hline Karakteristik Anak Balita dan Ibu & Frekuensi & Persentase (\%) \\
\hline Jenis Kelamin Anak Balita & 35 & \\
Perempuan & 35 & 50,00 \\
Laki-Laki & 53 & 50,00 \\
Tingkat Pendidikan & 17 & 75,71 \\
Rendah & & 24,29 \\
Tinggi & 33 & \\
Penghasilan Keluarga & 37 & 47,14 \\
Rendah & & 52,86 \\
Tinggi & 58 & \\
Pekerjaan Ibu & 12 & 82,86 \\
Bekerja & & 17,14 \\
Tidak Bekerja & & \\
\hline
\end{tabular}

Balita mempunyai proporsi jenis kelamin yang sama antara perempuan dan lakilaki. Sedangkan pada Responden ibu, sebagian besar berpendidikan rendah $(75,71 \%)$ dan memiliki pekerjaan $(82,86 \%)$. Orang tua balita sebagian besar berpenghasilan tinggi diatas UMR (52,86\%).

\section{Distribusi Status, Ketepatan Pemberian Imunisasi dan Kejadian Campak \\ Distribusi sampel berdasarkan status imunisasi, ketepatan pemberian imunisasi campak dan kejadian campak yang disajikan berikut ini:}


Tebel 2 Distribusi Frekuensi Status, Ketepatan Pemberian Imunisasi dan Kejadian Campak

\begin{tabular}{lll}
\hline Variabel & Frekuensi & Persentase (\%) \\
\hline Status Imunisasi & & \\
Tidak Dapat & 18 & 25,71 \\
Dapat & 52 & 74,29 \\
Ketepatan Pemberian & & \\
Tidak Tepat & 22 & 31,43 \\
Tepat & 48 & 68,57 \\
Kejadian Campak & & \\
Tidak Pernah & 58 & 82,86 \\
Pernah & 12 & 17,14 \\
\hline
\end{tabular}

Hasil penelitian menunjukkan sebagian besar anak balita telah mendapatkan imunisasi campak (74,29\%), pemberian imunisasi campak yang diberikan dengan tepat waktu $(68,57 \%)$ dan terdapat anak balita yang pernah terkena penyakit campak (17,14\%).

\section{Karakteristik Responden dengan Kejadian Campak pada Anak Balita}

Karakteristik responden Ibu meliputi tingkat pendidikan ibu, penghasilan keluarga dan pekerjaan ibu dengan kejadian campak pada anak balita disajikan sebagai berikut:

Tabel 3 Karakteristik Responden dengan Kejadian Campak

\begin{tabular}{|c|c|c|c|}
\hline \multirow{3}{*}{$\begin{array}{l}\text { Karakteristik } \\
\text { Responden }\end{array}$} & \multicolumn{2}{|c|}{ Campak } & \multirow{3}{*}{$\mathrm{PR}(95 \% \mathrm{CI})$} \\
\hline & \multirow{2}{*}{$\begin{array}{l}\text { Pernah } \\
\mathrm{n}(12)\end{array}$} & \multirow{2}{*}{$\begin{array}{l}\text { Tidak Pernah } \\
\mathrm{n}(58)\end{array}$} & \\
\hline & & & \\
\hline \multicolumn{3}{|l|}{ Tingkat Pendidikan } & \multirow[t]{3}{*}{$1,04(0,32-3,41)$} \\
\hline Rendah & $9(16,98 \%)$ & $44(83,02 \%)$ & \\
\hline Tinggi & $3(17,65 \%)$ & $14(82,35 \%)$ & \\
\hline \multicolumn{3}{|l|}{ Penghasilan Keluarga } & \multirow[t]{3}{*}{$1,57(0,55-4,47)$} \\
\hline Rendah & $7(21,21 \%)$ & $26(78,79 \%)$ & \\
\hline Tinggi & $5(13,51 \%)$ & $32(86,49 \%)$ & \\
\hline \multicolumn{3}{|l|}{ Pekerjaan } & \multirow[t]{3}{*}{$0,97(0,24-3,86)$} \\
\hline Bekerja & $10(17,24 \%)$ & $48(82,76 \%)$ & \\
\hline Tidak Bekerja & $2(16,67 \%)$ & $10(83,33 \%)$ & \\
\hline \multicolumn{2}{|c|}{$\begin{array}{l}\text { Hasil dari penelitian menunjukkan bahwa } \\
\text { Ibu dengan pendidikan rendah sebagian } \\
\text { besar anak balitanya tidak pernah } \\
\text { menderita campak }(83,87 \%) \text {, begitupun } \\
\text { juga ibu yang berpendidikan tinggi. } \\
\text { Keluarga dari anak balita yang memiliki } \\
\text { penghasilan rendah, sebagian besar anak }\end{array}$} & \multicolumn{2}{|c|}{$\begin{array}{l}\text { balitanya tidak pernah menderita campak } \\
(78,79 \%) \text {, begitu juga dengan keluarga } \\
\text { yang berpenghasilan tingggi atau melebihi } \\
\text { UMR. Ibu yang bekerja sebagaian anak } \\
\text { balitanya tidak pernah menderita campak } \\
(82,70 \%) \text {, begitupun juga dengan ibu yang } \\
\text { tidak bekerja. }\end{array}$} \\
\hline
\end{tabular}


Status Imunisasi, Ketepatan Pemberian Imunisasi dengan Kejadian Campak
Status imunisasi, ketepatan pem-berian imunisasi dengan kejadian campak pada anak balita disajikan sebagai berikut.

Tabel 4 Status Imunisasi, Ketepatan Pemberian Imunisasi dengan Kejadian Campak

\begin{tabular}{llll}
\hline \multirow{2}{*}{ Variabel } & \multicolumn{2}{l}{ Kejadian Campak } & PR (95\% \\
\cline { 2 - 3 } & Ya & Tidak & \\
\cline { 2 - 3 } & $\mathrm{n}(12)$ & $\mathrm{n}(58)$ & $14,44(3,49-$ \\
Status Imunisasi & & & $59,78)$ \\
Tidak Dapat & $10(55,56 \%)$ & $8(44,44 \%)$ & $24(3,3-$ \\
Dapat & $2(3,85 \%)$ & $50(96,15 \%)$ & $174,5)$ \\
Ketepatan & & & \\
Pemberian & & $11(50,00 \%)$ & \\
Tidak Tepat & $11(50,00 \%)$ & $47(97,92 \%)$ & \\
Tepat & $1(2,08 \%)$ & & \\
\hline
\end{tabular}

Hasil penelitian menunjukkan bahwa pada anak balita yang tidak mendapat imu-nisasi campak sebagian besar pernah men-derita campak (55,56\%), sedangkan anak balita yang telah mendapatkan imunisasi campak masih ada yang terkena penyakit camapak $(3,85 \%)$.

Pada anak balita yang diberikan imunisasi campak dengan tidak tepat waktu ternyata memiliki proporsi yang sama antara yang pernah menderita campak dengan tidak pernah menderita campak $(50,00 \%)$. Sedangkan pada anak balita yang sudah diberikan imunisasi campak dengan tepat waktu, namun masih ada yang menderita campak $(2,08 \%)$.

\section{DISKUSI}

\section{Status Imunisasi Campak pada Anak Balita di Puskesmas Nusa Penida I}

Penelitian ini menunjukkan sebagian besar anak balita telah mendapatkan imunisasi campak (74,29\%), sebagian lagi tidak memperoleh imunisasi. Dari 25,71\% anak balita yang tidak mendapatkan imunisasi, sebagian besar menderita campak (55,56\%).

Cakupan imunisasi campak pada penelitian ini masih kurang dari standar yaitu $74,29 \%$, sehingga memungkinkan untuk terjadinya penularan campak pada anak balita populasi rentan. Menurut Chin (2000), daerah dengan cakupan imunisasi $<90 \%$ masih rentan terhadap kejadian campak karena belum terbentuk kekebalan kelompok (herd imunity).

Herd Imunity merupakan tingkat resistensi suatu kelompok terhadap serangan penyakit, sebagian besar individunya telah di imunisasi, sehingga mengurangi individu sakit menularkan penyakitnya kepada individu yang rentan (Fine, 1993).

Kekebalan kelompok pada anak balita di penelitian ini dapat dikatakan belum terbentuk secara maksimal. Karena masih diketemukan anak balita yang pernah menderita campak, pada kelompok yang yang telah diberikan imunisasi campak (3,85\%). 
Hasil cross tabulasi antara status imunisasi dengan kejadian campak memiliki prevalensi campak lebih banyak pada anak balita yang tidak mendapatkan imunisasi campak dari pada yang dapat, dengan perbandingan $55,56 \%$ berbanding 3,85\%, nilai $\mathrm{PR}=14,44 ; 95 \% \mathrm{CI}(3,49-59,78)$, menunjukkan bahwa status imunisasi sebagai faktor risiko terjadi campak.

Penelitian ini sejalan hasil penelitian Suardiyasa (2008), menunjukkan bahwa status imunisasi merupakan variabel yang berhubungan dengan kejadian penyakit campak pada balita di Kabupaten Toli-Toli, dimana status imunisasi mempunyai nilai OR sebesar 38,089 (95\% CI: 16.592-87,438).

Sejalan dengan penelitian Duski (2001), menyatakan bahwa ada hubungan status imunisasi campak dengan kejadian campak. Anak yang tidak diimunisasi 3,2 kali lebih besar berisiko untuk menderita campak dibandingkan anak yang diimunisasi.

Kejadian campak tidak hanya di pengaruhi oleh status pemberian imunisasi dan cakupan imunisasi di suatu wilayah yang sebagai faktor risiko utama, tetapi berpengaruh pula oleh faktor lain seperti rantai dingin, mutu pelayanan kesehatan yang terkait. (Kusnanto et all,1997).

\section{Ketepatan Pemberian Imunisasi Campak pada Anak Balita}

Penelitian ini menunjukkan sebagian besar ibu telah memberikan imunisasi campak pada anak balita dengan tepat waktu $(68,57 \%)$, dan sebagian lagi memberikan imunisasi melebihi umur balita 11 bulan.
Anak balita yang diberikan imunisasi campak dengan tidak tepat waktu, ternyata memiliki proporsi yang sama antara yang pernah menderita campak(50,00\%) dengan tidak pernah menderita campak. Namun pada anak balita yang sudah diberikan imunisasi campak dengan tepat waktu, ternyata masih ada yang menderita campak (2,08\%).

Kekebalan alami campak dari ibu (maternal antibody) kepada bayi paling lama bertahan pada bayi sampai usia 9 bulan, maka selebihnya harus diberikan imunisasi buatan untuk mendapatkan kekebalan yang permanen. (Dirjen P2PL 2009).

Hasil cross tabulasi pada penelitian ini antara ketepatan pemberian imunisasi dengan kejadian campak memiliki prevalensi kejadian campak lebih banyak pada anak balita yang pemberian imunisasinya tidak tepat waktu dari pada yang tepat waktu, dengan perbandingan $50,00 \%$ berbanding 2,08\%. Dimana nilai $\mathrm{PR}=24$ (95\% CI: 3,3-174,5), menunjukkan bahwa ketepatan waktu pemberian imunisasi sebagai faktor risiko terjadi campak.

Penelitian ini sejalan dengan hasil dari penelitian oleh Miarti (2012), balita yang imunisasi tidak tepat waktu dan imunisasi tepat waktu dengan kejadian penyakit campak bernilai OR 3,085 (CI: 1,793-5,307) bermakna secara statistik dengan nilai $\mathrm{p}=0,000$.

Hasil penelitian ini dipertegas dengan hasil yang diperoleh Tri Budi (2015), bayi dan balita yang mendapatkan imunisasi campak tidak tepat waktu (usia lebih 11 bulan) kemungkinan mengalami 
kejadian campak 3,852 kali lebih besar dibandingkan dengan yang mendapatkan imunisasi campak tepat waktu (9-11 bulan).

Berdasarkan hasil wawancara dengan salah satu responden yang telah memberikan imunisasi, alasan utama tidak memberikan secara tepat waktu pada rentang usia bayi 9-11 bulan dikarenakan lupa, dan mengetahui pemberian imunisasi campak tersebut pada umur bayi 1 tahun. Sehingga masih terjadi penularan penyakit campak pada anak yang telah terimunisasi $(55,56 \%)$, karena tidak di berikan imunisasi secara tepat waktu pemberiannya $(2,08 \%)$.

Menurut Suwarnisih ketpatan dalam pemberian imunisasi pada bayi sesuai jadwal dan umur bayi sama dengan ketaatan kunjungan imunisasi. Ketepatan bisa diartikan tepat waktu, kejituan, alat ukur tersebut dapat dijamin (Ikatan Dokter Anak Indonesia, 2008).

\section{SIMPULAN}

Adapun kesimpulan dalam hasil penelitian ini yakni sebagian besar anak balita telah mendapatkan imunisasi dasar campak $74,29 \%$, namun terdapat anak balita yang mengalami kejadian campak klinis dengan proporsi 3,85\% ( $p=14,44)$. Sebagian besar anak balita telah diberikan imunisasi dasar campak dengan tepat waktu usia 9-11 bulan 68,57\%, namun terdapat anak balita yang pernah mengalami kejadian campak klinis dengan proporsi $2,08 \% \quad(p=24)$. Terdapat anak balita yang pernah terkena penyakit campak klinis $17,14 \%$ di daerah yang pernah mengalami KLB Campak Nusa Penida.

\section{SARAN}

Adapun saran yang dapat diberikan yakni bagi instansi terkait seperti Dinas Kesehatan dan Puskesmas perlu adanya cross data hasil penelitian mengenai cakupan imunisasi dasar campak dengan laporan cakupan imunisasi program Puskesmas, untuk mengkonfirmasi keadaan imunisasi dilapangan dan sebagai data perbandingan. Serta perlu dilakukan sosialisasi kepada masyarakat mengenai informasi pemberian imunisasi harus diberikan tepat pada waktunya. Konfirmasi Laboratorium; guna mengetahui yang pernah terkena campak agar diketahui bahwa benar terjangkit virus campak atau penyakit lainnya, sehingga akan lebih tepat dalam tindakan pengobatan dan perlu dipublikasikannya hasil uji laboratorium tersebut. Bagi penelitian selanjutnya sangat perlu melihat rantai dingin penyimpanan vaksin dan perlunya melihat efektivitas pemberian imunisasi campak lanjutan yang diberikan ketika umur anak balita 2 tahun. Karena dari hasil penelitian dengan nilai PR yang tinggi pada kedua variabel, telah dibuktikan bahwa merupakan faktor risiko terjadinya campak, walaupun dengan rentang CI yang lumayan lebar.

\section{DAFTAR PUSTAKA}

Chin, James, The American Public Health Association, (2000), Pemberantasan Penyakit Menular, Edisi 17 tahun Editor penerjemah: Dr. I Nyoman Kandun, MPH.

Departemen Kesehatan RI, Ditjen PP \& PL (2009)a. Pedomen Pelaksanaan Kampanye Imunisasi Campak dan Polio Tahun 2009-2010. Jakarta: 
Departemen Kesehatan RI, Ditjen PP\&PL.

Departemen Kesehatan RI, Ditjen PP \& PL (2009)b. Pedoman Penyilidikan Dan Penanggulangan Kejadian Luar Biasa Penyakit Menular Dan Keracunan, Direktorat P2PL. Jakarta Departemen Kesehatan RI. (2005), Keputusan menteri kesehatan RI tentang Pedoman Penyelenggaraan Imunisasi, Jakarta.

Dinas Kesehatan Provinsi Bali (2016), Profil Dinas Kesehatan Provinsi Bali 2015. Denpasar: Dinas Kesehatan Provinsi Bali.

Dinas Kesehatan Provinsi Bali (2016), Laporan Penelusuran KLB Campak Nusa Penida 2016. Denpasar: Dinas Kesehatan Provinsi Bali.

Dinas Kesehatan Provinsi Klungkung (2016), Profil Dinas Kesehatan Provinsi Klungkung 2015. Semarapura: Dinas Kesehatan Provinsi Klungkung.

Duski, Oki, (2001) Hubungan Status Imunisasi Campak Dengan Kejadian Campak pada Anak Usia Dibawah 5 Tahun Saat Peristiwa Wabah Campak Di Desa Pagerageung Kecamatan Pagerageung Kabupaten Tasikmalaya Tahun 2000. Tesis, Program Studi Epidemiologi Kekhususan Epidemiologi Lapangan. Program Pasca Sarjana UI. Jakarta.

Fine, Paul. 1993. Herd Immunity: History, Theory, Practice. Epidemiologic Reviews Vol. 15 No.2, John Hopskins University, School of Hygiene and Public Health.
Ikatan Dokter Anak Indonesia, Satgas Imunisasi (2008), Pedoman Imunisasi di Indonesia, Badan Penerbit Ikatan Anak Dokter Indonesia, Jakarta.

KemenKes RI. 2013. Profil Kesehatan Indonesia 2012. Jakarta: Kementerian Kesehatan Republik Indonesia.

KemenKes RI. 2016. Profil Kesehatan Indonesia $2015 . \quad$ Jakarta: Kementerian Kesehatan Republik Indonesia.

Kusnanto, H. Wilopo,S.A. Sarjono, A. Rusito,H. (1997) Pencapaian Program Imunisasi pada Anak Usia 12-23 bulan di Kabupaten Purworejo, Laboratorium Penelitian Kesehatan dan Gizi Masyarakat,FK, UGM, Yogyakarta.

Miarti (2012), Hubungan Pemberian Imunisasi Campak Dengankejadian Penyakit Campak Klinis Di Kabupaten Banyumas. Tesis, Program Studi Ilmu Kesehatan Masyakat Minat Utama Epidemiologi Lapangan. Pasca Sarjana Universitas Gajah Mada, Yogyakarta

Puskesmas Nusa Penida 1 (2016), Profil Puskesmas Nusa Penida 12016. Semarapura: Puskesmas Nusa Penida 1, Klungkung.

Suardiyasa, I M (2008) Faktor-Faktor Risiko Kejadian Penyakit Campak pada Balita di Kabupaten Tolitoli propinsi Sulawesi Tengah. tesis, UGM, Yogyakarta.

Suwarnisih (2012). Ketepatan jadwal pemberian imunisasi campak pada bayi di Rumah Bersalin Ibunda 
Arc. Com. Health • Juni 2019

ISSN: 2527-3620

Vol. 6 No. 1 : 47 - 55

Jaten Karanganyar. Jurnal Maternal Volume 6 Edisi April 2012; 2012.

2013-2014. Stikes Aisyiyah Yogyakarta.

Tri Budi Yanti, Sulistyaningsih (2015), Hubungan Pemberian Vitamin A dan Umur Saat Pemberian Imunisasi Campak Dengan Kejadian Campak Pada Bayi Dan Balita Di Kabupaten Bantul Tahun

World Health Organization (2009) Global Immunization Data [Accessed 25Januari2017]http://www.who.int/i mmunization_monitoring/Global_I mmunization_Data.pdf. 